\title{
Improving the Students' Writing Skills by Using Track Changes in Paired Writing Correction
}

\author{
Putri Rahmayanti \\ Islamic School Harapan Mulia, Bali, Indonesia \\ Corresponding Author: poetryrahma@gmail.com \\ I Gede Oka \\ SMA Negeri 2 Singaraja, Bali, Indonesia \\ I Nyoman Adi Jaya Putra \\ English Education Department, Universitas Pendidikan Ganesha, Bali, Indonesia
}

\begin{abstract}
Researchers made observations during the writing class. There were several writing problems faced by students, including: spelling errors in writing a few words, difficulty in compiling ideas, grammatical errors, incorrect punctuation, and inaccurate diction used. The researcher then found a solution to that problem by using the track changes feature in the pair correction activity. Track changes was useful for correcting students' writing in the editing phase not only making corrections, students also worked together in groups in pairs to produce better writing. The study used a classroom action research that aimed to describe the implementation of the use of track changes in pair correction activities and to find out whether the strategy could improve students' writing skills. The subjects of this study were students in class XI IPA 1 with a total of 32 students. The procedures in this study included planning, action, observation, and reflection. Researchers collected data through pre-test, post-test, questionnaire, and interview. The researcher used two cycles in this research. The results of the pre-test action showed that the average grade of the class was 67, after implementing the strategy, the average class in the first post test was 79 and in the second post-test it was 81 . Based on these results, the use of track changes in writing correction in pairs could improve students' writing skills. The data were also supported by the results of questionnaires and interviews obtained that track changes helped students in learning to write.
\end{abstract}

Keywords: Paired Correction, Track Changes, Writing

\section{INTRODUCTION}

There are four English skills that must be mastered by students. Those are listening, speaking, writing, and reading. Among the four skills, writing skill is considered as an important skill by the teacher. Because writing skill is an ongoing process experienced by students, and this is difficult compared to speaking, reading, and listening. Learners do not only write what is in their minds, but also arrange ideas to make unified and interconnected. The ability to write in English also requires students to pay attention to grammar, punctuation, spelling, vocabulary selection, and etc. Hyland (2004: 3) states 
that the most important thing from writing is seen as a product arranged by the writer based on grammar and knowledge to arrange words or sentences, the development of students' writing depends on the results of developing examples given by the teacher. Therefore, students need to be trained to have a good writing skill while learning, besides writing skill is currently very much needed such as writing for research reports, journals, articles, web blogs, job applications, and etc.

However, the students of XI IPA 1 of SMAN 2 Singaraja still faced some difficulties in writing class. During the teaching practice, the researchers found that students were still experiencing difficulties in writing, such as misspelling a few words in writing, having difficulty in compiling ideas, making grammatical errors and incorrect punctuation, and using inappropriate diction. The problems were found in the results of essay assignments of cause and effect given by the teacher. From the results of the essay that was done only 13 children from 32 students whose score reached above the standard (KKM). 19 students still experienced problems in writing, on average they experienced errors in grammar and spelling, as in sentences: Because of she is lazy, her freinds are stay away from her. There are also a number of paragraphs that do not have the appropriate periods and commas, which results in students' writing scores being low or less than standard (KKM). In addition, researchers also paid attention to the learning process carried out by the teacher who taught in that class. The teacher focused more on the exercises on the students' worksheets, and students only wrote a few short and simple sentences. Students also got little chance to produce writing products.

To overcome the writing problems faced by students, they could take advantage of the use of technology through Track Changes. This text editing application can be found in Microsoft Word. The author can easily provide comments, revise, and ask questions that are considered to be less clear in writing. Moreover, the writer can also accept or reject the revision given if it is not appropriate (Harmer, 2004). Based on the results of research conducted by Aksit (2009) entitled "Using Track Changes in Microsoft Word to Correct Student Writing" the results of the questionnaire given to students showed that as much as $70 \%$ of students learn from errors corrected by their friends. The process for developing writing skills can also be done with the existence of peer correction (paired correction), so that students can see examples of their friends' writing. Students can also give opinions or ideas to an article and learn to revise each other. The results of a class action research conducted by Syakirman (2016) entitled "Using Peer Editing to Improve Students' Writing Skill" proves that paired correction can increase the value of students in writing ability from $49.6 \%$ of the pre-test results to $67.4 \%$ in the first post test and $72.9 \%$ in the second post-test. Students are also motivated, interested, and helped in the writing process. Based on this background, researchers conducted classroom action research to investigate whether the use of track changes in paired corrections could improve students' writing skills or vice versa. 


\section{METHOD}

\section{Research Settings and Research Subjects}

This Classroom Action Research was conducted at SMA 2 Singaraja in the second semester of the 2018/2019 academic year for 4 months starting from February - May 2019. The research subjects in this study were students of class XI IPA 1 at SMAN 2 Singaraja in the 2018/2019 school year with a total of 32 students in one class consisting of 7 male and 25 female students.

\section{Research Instrument}

This study used observation as an instrument in to collect factual data in the classroom during the teaching-learning process. Another instrument used was the test. In this study, 2 tests were conducted. The first test, done at the beginning of learning, was aimed to know students' achievement in writing skills. The next research instrument was a questionnaire containing several questions which were answered by students. The questionnaires were distributed using Google form. Researchers also used structured interviews to collect data in depth and in detail from the students.

\section{Research Procedure}

The researcher conducted at least two cycles using the class action research model from Kemmis and Taggart (1992). The following is an explanation of each of the stages of research in implementing track changes in paired writing correction in English subject with the topic of explanatory text material:

\section{Planning Phase}

The researchers designed an interactive learning implementation plan to solve the problem using track changes in paired correction on writing skills. The researchers selected the topic to be used and prepared the instruments (observation, test, interview and questionnaire).

\section{Stage of Action and Observation}

Researchers carried out the steps of learning using track changes in paired writing correction according to plan. Researchers did observations at each step of the planning phase. Observations were carried out during the implementation of the action by using prepared observation sheets and recording incidents that were not contained in the observation sheet by making a field note sheet (field note). The things observed during this phase were activities during the implementation of track changes in class. Anticipation was done by finding solutions to problems that might be encountered during the activity stage.

\section{Reflection Phase}

Evaluating the implementation of actions in the first cycle included analysis, synthesis, giving meaning, explanations, and conclusions of the collected data and information. The data and information were used as consideration for planning the implementation of learning using track changes in pair correction in the next cycle. 


\section{Data collection techniques}

Researchers conducted a pre-test to collect the data. The test was in the form of an essay test. There was not a specific topic given to participants, but the topics were just adjusted to the learning material which was being studied by students. To find out how the class conditions and situations when applying track changes in pair correction, researchers used observations equipped with observation sheets. Furthermore, researchers conducted a post-test in the form of writing performance as a result of the application of the techniques that have been carried out. Researchers conducted interviews with several students to find out in depth and detailed information about the difficulties and conveniences obtained from using Track Changes. Questionnaires were given online after the results of the post-test had been obtained and reached the target. The questionnaire also contained data about the attitudes and opinions of students after implementing the strategy.

\section{Data Analysis}

Descriptive quantitative was used to analyze data results. Data analysis was done by using the average score of students in class as follows:

$$
\mathrm{x}=\frac{\Sigma x}{N}
$$

\section{Note:}

$\mathrm{x}=$ students average score

$\Sigma^{\mathrm{x}}=$ student individual score $\left(\mathrm{n}_{1}+\mathrm{n}_{2}+\ldots \ldots+\mathrm{nx}\right)$

$\mathrm{N}=$ total of the students

The data that has been obtained were analyzed using comparison assessment techniques where the pre-test results were compared to post-test results. Further, the results of comparing the tests would show the level of improvement that occurred after implementing Track Changes in paired writing correction activities in class XI Science. Then, the researchers analyzed the results of the questionnaire and interview to find out the difficulties and problems encountered.

\section{Performance Indicators}

The indicators that served as benchmarks for the success of this Classroom Action Research are as follows: (1) Students are said to increase their abilities if they can achieve the five aspects of writing, among others: content, organization, grammar, vocabulary, and mechanic; and (2) Each students score can increase at least 5 digits above the KKM with a minimum score of 73 as much as $75 \%$.

\section{FINDINGS AND DISCUSSION}

\section{Pre-Test}

Before implementing a strategy to overcome the problems that arose in class XI IPA 1 which were the result of preliminary observations, the researcher conducted a pretest. The purpose of conducting this pre-test was to check the problems that occurred related to students' writing ability in organizing ideas, content suitability, spelling writing, grammar use, and mechanics in writing: 
Table 1. The student's Writing Score for Pre-test

\begin{tabular}{clc}
\hline No. & \multicolumn{1}{c}{ Nama } & Skor \\
\hline 1 & David Rudiyanto & 70 \\
\hline 2 & Dhiyo Ketut & 85 \\
\hline 3 & Gede Satya Anggara & 63 \\
\hline 4 & I Putu Divtya Bandawa & 60 \\
\hline 5 & I Putu Teguh Ari & 58 \\
\hline 6 & Ida Ayu Komang Trisna & 90 \\
\hline 7 & Kadek Darmaswari & 80 \\
\hline 8 & Kadek Deva Nadya & 90 \\
\hline 9 & Kadek Dian Widiartini & 60 \\
\hline 10 & Kadek Ria Andriani & 60 \\
\hline 11 & Ketut Yudi Darma & 70 \\
\hline 12 & Komang Ayu Dipla & 55 \\
\hline 13 & Komang Jetli Rialdiesa & 67 \\
\hline 14 & Komang Sri Hermaliani & 55 \\
\hline 15 & Luh Kasih Sari Mertha & 70 \\
\hline 16 & Luh Lia Aprianti & 60 \\
\hline
\end{tabular}

\begin{tabular}{clc}
\hline No. & Nama & Skor \\
\hline 17 & Luh Putri Indra Dewi & 55 \\
\hline 18 & Made Anggiek & 60 \\
\hline 19 & Made Mitha Wedayanti & 80 \\
\hline 20 & Ni Gst.Nyoman & 70 \\
\hline 21 & Ni Kadek Sri Martini & 65 \\
\hline 22 & Ni Kadek Yuni Susila & 68 \\
\hline 23 & Ni Ketut Herdyanti & 60 \\
\hline 24 & Ni Luh Arik Setiawati & 60 \\
\hline 25 & Ni Putu Kirana & 68 \\
\hline 26 & Ni Wayan Eka Merliani & 60 \\
\hline 27 & Nyoman Sri Werdi & 90 \\
\hline 28 & Putu Ditha Ananda & 68 \\
\hline 29 & Putu Eka Aprilya & 70 \\
\hline 30 & Putu Rhena Yogi & 90 \\
\hline 31 & Radhatya Dhyan & 55 \\
\hline 32 & Valentina Dewi Yosoa & 55 \\
\hline
\end{tabular}

After finding the score of each student in the class, the researcher calculated the average value. In addition, researchers also calculated the presentation of students who had reached the standard score. The calculation is as follows:

$\Sigma$ Pre-Test $=2165$

Average Pre-Test score $=\frac{\sum \text { Pre-Test }}{\text { Jumlah Siswa }}$

$$
\begin{aligned}
& \frac{2165}{32} \\
= & 67
\end{aligned}
$$

Based on the results of the calculations, the researcher concluded that the average English writing ability in the class did not reach the determined score. Furthermore, because of the 32 students in the class, only 11 students reached the standard score (KKM), the presentation of the standard score (KKM) achievement in that class was $34 \%$.

\section{The Implementation of Cycle 1}

The cycle 1 consisted of one meeting. At the first meeting held on Thursday, March 28, 2019, researchers carried out the normal learning process by using Track Changes. The implementation of cycle 1 consisted of three stages: Plan, Act \& Observe, and Reflect. The details of each stage activities in research implementation are as follows;

\section{Plan}

Before carrying out learning using Track Changes in paired writing correction, the researcher with guidance from the collaborating teacher and lecturer did the Plan for learning.

\section{Action (Act and Observe)}

At the implementation stage, researchers did not only act as researchers but also as teachers and observers. The purpose of this stage was to implement the chosen strategy, 
which was to use the Track Changes in paired writing correction in order to solve the problems that appeared in class XI IPA 1 related to the students' ability in writing English. The following are examples of the results of corrections made by students in pairs using Track Changes:

Figure 1. The Example of Track Changes

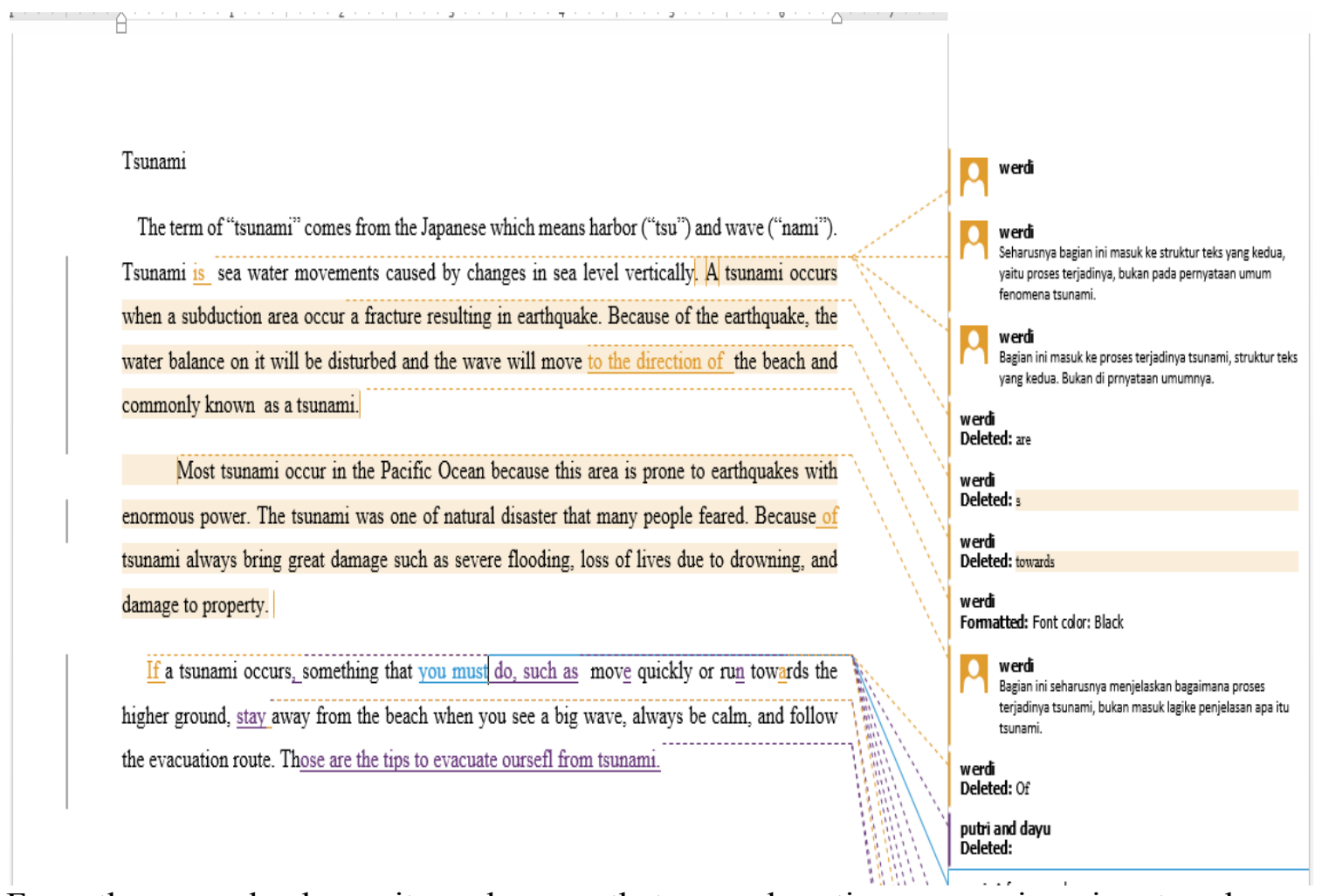

From the example above, it can be seen that several sections were given input such as: organizing ideas, appropriateness of text contents, vocabulary, and grammar. While the researcher, as a teaching teacher, delivered the material, the researcher also made observations. This observation activity aims to determine the response of students to each stage of learning that has been designed by researchers

\section{Reflection (Reflect)}

In the reflection stage, the researcher analyzed the results from the observation sheet. The researcher concluded that students gave a positive response to learning process by using the track changes in the pair writing correction that had been designed by the researcher. Furthermore, the results of the observation sheet also showed how the learning process in the cycle 1 could facilitate and assist students in writing skills.

\section{Results Test Post-1}

Post-test 1 was held at the first meeting followed by assignments and students collected the assignment in the next meeting on April 11, 2019 in the form of final draft.

Table 2. The student's Writing Score for Test Post-1

\begin{tabular}{|c|c|c|c|c|c|}
\hline No. & Nama & Skor & 4 & I Putu Divtya Bandawa & 87 \\
\hline 1 & David Rudiyanto & 90 & 5 & I Putu Teguh Ari & 82 \\
\hline 2 & Dhiyo Ketut & 90 & 6 & Ida Ayu Komang Trisna & 90 \\
\hline 3 & Gede Satya Anggara & 78 & 7 & Kadek Darmaswari & 83 \\
\hline
\end{tabular}




\begin{tabular}{clc}
\hline 8 & Kadek Deva Nadya & 88 \\
\hline 9 & Kadek Dian Widiartini & 78 \\
\hline 10 & Kadek Ria Andriani & 70 \\
\hline 11 & Ketut Yudi Darma & 87 \\
\hline 12 & Komang Ayu Dipla & 73 \\
\hline 13 & Komang Jetli Rialdiesa & 86 \\
\hline 14 & Komang Sri Hermaliani & 70 \\
\hline 15 & Luh Kasih Sari Mertha & 88 \\
\hline 16 & Luh Lia Aprianti & 73 \\
\hline No. & Nama & Skor \\
\hline 17 & Luh Putri Indra Dewi & 70 \\
\hline 18 & Made Anggiek & 83 \\
\hline 19 & Made Mitha Wedayanti & 90 \\
\hline
\end{tabular}

\begin{tabular}{lll}
\hline 20 & Ni Gst.Nyoman & 65 \\
\hline 21 & Ni Kadek Sri Martini & 70 \\
\hline 22 & Ni Kadek Yuni Susila & 63 \\
\hline 23 & Ni Ketut Herdyanti & 86 \\
\hline 24 & Ni Luh Arik Setiawati & 60 \\
\hline 25 & Ni Putu Kirana & 83 \\
\hline 26 & Ni Wayan Eka Merliani & 65 \\
\hline 27 & Nyoman Sri Werdi & 90 \\
\hline 28 & Putu Ditha Ananda & 86 \\
\hline 29 & Putu Eka Aprilya & 83 \\
\hline 30 & Putu Rhena Yogi & 90 \\
\hline 31 & Radhatya Dhyan & 78 \\
\hline 32 & Valentina Dewi Yosoa & 78 \\
\hline
\end{tabular}

Based on the students' scores in post-test 1 , the following is the average grade and percentage of students whose grades reached the standard score (KKM).

$\Sigma$ Post-Test $1=2553$

Average Post-Test score 1

$$
\begin{aligned}
= & \frac{\sum \text { Post-test }}{\text { lumlah Siswa }} \\
= & \frac{2553}{32} \\
= & 79,7
\end{aligned}
$$

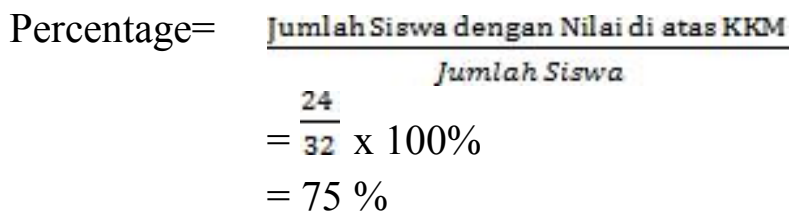

Based on these calculations, the researcher found that, in post-test 1 , the average score of students increased from 67.00 to 79.7. An increase in the average score of this class also affected the percentage of students who reached a predetermined standard score (KKM). If in the pre-test there were only students who scored above the standard score (KKM) only 11 students with a percentage of $34 \%$, the results of this post-test 1 showed that 24 out of 32 participants in the class scored above the standard score (KKM). So the percentage obtained was $75 \%$ of students in class XI Natural Sciences 1 had reached the standard score (KKM). So from the results of the post-test I increased by $41 \%$. Although there were still 8 students whose grades were still below the KKM, the results of the posttest still indicated an increase in score compared to the score obtained at the time of the pre-test. That way, researchers concluded that the Track Changes in paired writing correction in the learning process in class XI Science 1 could really help students in the class improving their writing skills in English subjects.

Implementation of learning using Track Changes in writing correction in pairs in a cycle 1 can be said to be going well. There were few problems at the implementation stage in the class, the number of students in the class were 32 people. Only 16 students 
had a laptop. However, the teacher could overcome the problem by asking the students working in pairs. Hence, they had to find a partner who had a laptop and worked together for the next activities.

Furthermore, based on the results of observations and post-test 1 that had been conducted during the learning process, researchers concluded that classroom action research using track changes in pairs to help students in class XI IPA 1 improve their English writing skills which includes content, organization, grammar, vocabulary, and mechanics met the first achievement indicator. This was proved by the increase of students score in post-test 1 compared to the score in the pre-test before this strategy was implemented. Unfortunately, the research in cycle 1 did not meet the second achievement indicator, that was the score of students should reach 5 points above the standard score (KKM) that had been determined by researchers on the indicators of success. There were 8 students who did not reach these criteria.

\section{The Implementation of Cycle 2}

Cycle 2 was conducted in two meetings on Thursday, 11 and 18 April in of class X Science 3. Cycle 2 also consisted of three stages, namely Plan, Act \& Observe, and Reflect. The planning stages in cycle 2 were carried out on 7 - 10 April 2019. The researcher started to compile lesson plans, choose the appropriate media, and arrange teaching materials that were appropriate to the topic to be taught. What distinguished planning in this cycle from the previous cycle was that the researcher compiles lesson plans and teaching materials by taking into account the results of the research in cycle 1 for consideration. In addition, the researchers also made activities that were slightly variable compared to cycle 1 . In the second cycle, students immediately learned to develop phrases into sentences which then became a paragraph. Due to the time constraints in class, at the implementation stage in the second cycle only ran from to drafting and planning. For editing the final draft phase would be continued in the next meeting, on April 18th. In the next meeting, students did the correction activities and still in pairs. The teacher gave 2 laptops to students so that those who did not bring a laptop could do it quickly without waiting for their friends. Before they started correcting, the teacher explained again the parts that needed to be revised. And the next stage, after revising, students corrected their writing based on the comments and suggestions of their partner friends. In determining pairs of groups, the teacher divided students based on the results of the first cycle. Students, who still did not reach the criteria in post-test 1, were paired up with friends who reached the indicator. The teacher did observations by going around the whole group to ensure students' performance. Sometimes the teacher also interacted with students; especially with students who in the previous cycle received scores that did not meet the standard score (KKM), to check their understanding of the correction to be done.

\section{Reflections}

Researchers found positive responses shown by students throughout the learning process. Positive responses were shown by students because the strategies used could 
help students to get to know their weaknesses and strengths in writing skills, help students in detecting mistakes they made, because in the track changes feature could easily detect errors especially on spelling, grammar, and punctuation. It also motivated students to be more active in communicating either with fellow friends or with teachers, and motivated students in participating in learning because they had new learning experiences with the use of technology, and helped students to exchange information in groups in pairs, if there were things that they did not understood. They felt more comfortable if the correction was done by his friend. The score of the second cycle post-test can be seen in the following table:

Table 3. The student's Writing Score for Test Post-2

\begin{tabular}{|c|c|c|}
\hline No. & Nama & Skor \\
\hline 1 & David Rudiyanto & 80 \\
\hline 2 & Dhiyo Ketut & 92 \\
\hline 3 & Gede Satya Anggara & 76 \\
\hline 4 & I Putu Divtya Bandawa & 80 \\
\hline 5 & I Putu Teguh Ari & 82 \\
\hline 6 & Ida Ayu Komang Trisna & 82 \\
\hline 7 & Kadek Darmaswari & 85 \\
\hline 8 & Kadek Deva Nadya & 85 \\
\hline 9 & Kadek Dian Widiartini & 87 \\
\hline 10 & Kadek Ria Andriani & 75 \\
\hline 11 & Ketut Yudi Darma & 80 \\
\hline 12 & Komang Ayu Dipla & 82 \\
\hline 13 & Komang Jetli Rialdiesa & 82 \\
\hline 14 & Komang Sri Hermaliani & 82 \\
\hline 15 & Luh Kasih Sari Mertha & 73 \\
\hline 16 & Luh Lia Aprianti & 75 \\
\hline
\end{tabular}

\begin{tabular}{clc}
\hline No. & Nama & Skor \\
\hline 17 & Luh Putri Indra Dewi & 82 \\
\hline 18 & Made Anggiek & 82 \\
\hline 19 & Made Mitha Wedayanti & 85 \\
\hline 20 & Ni Gst.Nyoman & 77 \\
\hline 21 & Ni Kadek Sri Martini & 82 \\
\hline 22 & Ni Kadek Yuni Susila & 82 \\
\hline 23 & Ni Ketut Herdyanti & 73 \\
\hline 24 & Ni Luh Arik Setiawati & 86 \\
\hline 25 & Ni Putu Kirana & 75 \\
\hline 26 & Ni Wayan Eka Merliani & 86 \\
\hline 27 & Nyoman Sri Werdi & 75 \\
\hline 28 & Putu Ditha Ananda & 78 \\
\hline 29 & Putu Eka Aprilya & 77 \\
\hline 30 & Putu Rhena Yogi & 90 \\
\hline 31 & Radhatya Dhyan & 82 \\
\hline 32 & Valentina Dewi Yosoa & 85 \\
\hline
\end{tabular}

The average score of class XI IPA 1 in the post-test 2 increased compared to the average score of the class obtained in the previous post-test 1 . This average score increased from 79.7 in cycle 1 to 81.25 . Comparable to the increasing grade average, the presentation of students who scored above the standard score (KKM) also increased. Based on calculations, the percentage of student achievement towards the specified KKM value was $100 \%$. This showed that all students in class XI IPA 1 managed to get a score above the standard score (KKM) in post-test 2.

\section{Results of Questionnaire}

After conducting the post-test in stages 1 and 2, researchers gave questionnaires to students. To find out more about the benefits gained during the learning using Track Changes in pairs. The results of the questionnaire were as follows: (1) Statement 1: "I got helped by using Track Changes in writing". The result showed that $64.9 \%$ agreed and $24.3 \%$ strongly agreed that Track Changes helped them in learning writing, especially in the editing process. While 10.8\% feel doubtful; (2) Statement 2: "Giving corrections using Track Changes was easier to accept than verbally”. The results showed that $67.6 \%$ of students agreed and $21 \%$ strongly agreed that the results of the corrections provided by their friends with the help of Track Changes were easy to accept; (3) Statement 3: "The features of Track Changes made correcting activities interesting". As many as 
$59.5 \%$ felt agreed and $21.6 \%$ strongly agreed that the correction using Track Changes was more interesting; (4) Statement 4: "I became more careful in writing after getting corrections from friends". From the results of subsequent statements, as many as $73 \%$ and 24.3\% felt more careful in writing after being corrected by their friends; (5) Statement 5: "I was able to overcome writing problems such as: organizing ideas, choosing words, grammar, punctuation, and spelling, after conducting paired correction activities using Track Changes". The results indicated that $75.7 \%$ of students agreed and $18.9 \%$ strongly agreed. Paired correction activities using Track Changes helped students overcame their writing problems; (6) Statement 6: "I corrected a friend in detail". The results showed that students agreed as much as $62.2 \%$ and $24.3 \%$ strongly agreed if they were careful in correcting the work of their friends; and (7) Statement 7: "The results of my writing were better after being corrected by a friend". As many as $81.1 \%$ of the students agreed and $13.5 \%$ felt that the results of the writing, they were working on had improved after doing a pair of correction activities with the help of Track Changes.

\section{DISCUSSION}

Learning English with the topic text Explanation using Track Changes in correction of writing in pairs was held in three meetings. This strategy was implemented in the core activities section of the learning process. Learning in the two meetings was carried out with the same steps. However, what distinguished it from the two was the variety of learning activities used.

The teacher acted as a facilitator and monitored the activities of students in class. After the final stage, the writings were collected to the teacher. The results of the writing were also still checked by the teacher. If there were some mistakes in the correction, the teacher would correct the students' writing, and redistributed the results of their writing, so they better understood the weaknesses and strengths they had in writing skills. The teacher during the learning process also acted as a collaborator with students to help them improving their writing skill.

Implementing the use of this strategy in the learning process together ended with a post-test conducted after the strategy was implemented. The implementation of this posttest aimed to assist researchers in checking the development of English reading skills possessed by students compared to before this strategy was used in the classroom.

Based on the results of the pre-test, the researchers found that almost all students in the class experienced difficulties in writing skills. This was indicated by the score of those who did not reach the standard score (KKM) value set by the school. After further calculations, the researcher found that the average grade of the class was 67 with a percentage of students who scored above the KKM only as many as 11 students. That way, the use of Track Changes in any paired writing correction was implemented in the class in learning cycle 1. After learning to use track changes in paired group correction in cycle 1 , the researcher conducted a post-test 1 of the results, the researchers found that all students in the class had increased. The average score of students experienced an increase from 67.00 to 79.7. At the next meeting after learning in cycle 2 was carried out, the researcher carried out post-test 2. Based on the results obtained, this average score increased from 79.7 in cycle 1 to 81.25 in cycle 2 . Comparable to the increasing score 
average, the presentation of students who scored above the standard score (KKM) also increased. Based on calculations, the percentage of student achievement towards the specified standard score (KKM) was $100 \%$. Thus, this showed that the use of Track Changes for paired correction activities in learning English could help students improving their writing skill.

\section{CONCLUSIONS}

This class action research was carried out because of the emergence of a learning problem in one of the classes at SMA Negeri 2 Singaraja after the initial observation, which was class XI Science 1. The problem that arose was that the ability to write English in the class was still lacking. More specifically, the learning problems faced by students in the class were their ability to organize ideas, grammar, mechanics, and vocabulary. This was proven from the results of the pre-test which showed that only 11 students out of 32 people could achieve the standard score (KKM) determined by the school for English subjects, which is 68 .

Furthermore, by using Track Changes in correcting activities in pairs, the researcher tried to overcome the learning problems associated with the students' English writing ability. From the results of the pre-test, post-test 1, post-test 2, and observations during the learning process, the researcher concluded that implementing Track Changes in the class could really help students improve their writing skill. This was proven by the results of grades that continued to increase until all students in the class could get score above the standard (KKM). In addition, students also showed a positive response to the strategies used by teachers in the classroom. This was indicated by the activeness of students in participating in each stage of learning activities in the classroom, and they felt they were able to accept the correction results received by the partner his group.

\section{ACKNOWLEDGMENTS}

The authors thank to the Principal, English teachers and students Class XI IPA 1 of SMAN 2 Singaraja for conducting Classroom Action Research in accordance with the specified schedule and conditions. This report serves as a part of requirement during the implementation of PPL for PPG (Pendidikan Profesi Guru) academic year 2018/2019, granted by Ministry of Education with the partnership, Universitas Pendidikan Ganesha.

\section{REFERENCES}

Aksit, Zeynep. (2009) Using Track Changes in Microsoft Word to Correct Student Writing. Proceedings of the 10th METU ELT

Creswell, J.H. (2011) Educational Research: Planning, Conducting, and Evaluating

Quantitative and Qualitative Research, Fourth Edition. New York: Pearson EducationInc.

Harmer, J. (2004) How to Teach Writing. England: Pearson Education

Hyland,K. (2004) Second Language Writing. New York: Cambridge University Press

Kemmis, S., \& Taggart, R. Mc. (1992). The Action Research Planner. Victoria: Deakin

University.

Syakirman, Ahmad. (2016) Using Peer Editing to Improve Students' Writing Skill.

Bengkulu: Literary Critism Journal vol. 3 no 2 
Birnholtz, Jeremy. Ibara, Steven. (2012) Track Changes in Collaborative Writing: Edits, Visibility and Group Maintanance. Seattle: Session Four Life Stages

Dalman. (2015) Keterampilan Menulis.Jakarta: Raja Grafindo Persada

Nation, I.S.P. (2009) Teaching ESL/EFL Reading and Writing. New York: Routledge Taylor and Francis

Scrivener, Jim. (2010) The Essential Guide to English Language Teaching Third Edition. MacMillan 